\title{
About the consistency between Envisat and CryoSat-2 radar freeboard retrieval over Antarctic sea ice
}

\author{
Sandra Schwegmann ${ }^{1}$, Eero Rinne ${ }^{2}$, Robert Ricker ${ }^{1}$, Stefan Hendricks ${ }^{1}$, and Veit Helm ${ }^{1}$ \\ ${ }^{1}$ Alfred Wegener Institute, Helmholtz Centre for Polar and Marine Research, Am Handelshafen 12, \\ 27570 Bremerhaven, Germany \\ ${ }^{2}$ Finnish Meteorological Institute, Marine Research, Erik Palménin aukio 1, 00560 Helsinki, Finland \\ Correspondence to: Sandra Schwegmann (sandra.schwegmann@bsh.de)
}

Received: 26 June 2015 - Published in The Cryosphere Discuss.: 16 September 2015

Revised: 6 June 2016 - Accepted: 8 June 2016 - Published: 8 July 2016

\begin{abstract}
Knowledge about Antarctic sea-ice volume and its changes over the past decades has been sparse due to the lack of systematic sea-ice thickness measurements in this remote area. Recently, first attempts have been made to develop a sea-ice thickness product over the Southern Ocean from space-borne radar altimetry and results look promising. Today, more than 20 years of radar altimeter data are potentially available for such products. However, the characteristics of individual radar types differ for the available altimeter missions. Hence, it is important and our goal to study the consistency between single sensors in order to develop long and consistent time series. Here, the consistency between freeboard measurements of the Radar Altimeter 2 on board Envisat and freeboard measurements from the SyntheticAperture Interferometric Radar Altimeter on board CryoSat2 is tested for their overlap period in 2011. Results indicate that mean and modal values are in reasonable agreement over the sea-ice growth season (May-October) and partly also beyond. In general, Envisat data show higher freeboards in the first-year ice zone while CryoSat-2 freeboards are higher in the multiyear ice zone and near the coasts. This has consequences for the agreement in individual sectors of the Southern Ocean, where one or the other ice class may dominate. Nevertheless, over the growth season, mean freeboard for the entire (regionally separated) Southern Ocean differs generally by not more than $3 \mathrm{~cm}(8 \mathrm{~cm}$, with few exceptions) between Envisat and CryoSat-2, and the differences between modal freeboards lie generally within $\pm 10 \mathrm{~cm}$ and often even below.
\end{abstract}

\section{Introduction}

Over the last 3 decades, sea-ice extent (SIE) in the Arctic has decreased and submarine ice draft measurements indicate that also sea-ice volume is declining (Rothrock et al., 1999, 2008; Lindsay and Schweiger, 2015). In the Antarctic, in contrast, SIE is increasing, but little is known about the changes in sea-ice volume. This is due to the lack of systematic sea-ice thickness measurements in the Southern Hemisphere. There are only few in situ data sets from upwardlooking sonars (only Weddell Sea; e.g., Harms et al., 2001; Behrendt et al., 2013), drillings (e.g., Lange and Eicken, 1991; Ozsoy-Cicek et al., 2013; Wadhams et al., 1987; Perovich et al., 2004), electromagnetic methods (Haas, 1998; Weissling et al., 2011; Haas et al., 2008) and airborne altimetry (e.g., Dierking, 1995; Leuschen et al., 2008). Those data are distributed unevenly in location, coverage and time and do not allow for the estimation of seasonal and interannual sea-ice volume changes. Only ship-based visual observations (ASPeCt, Worby et al., 2008) have been used for estimations of the seasonal variability in selected regions. Hence, in order to investigate current mass balance and feedback mechanisms of the entire Antarctic sea-ice zone we need sea-ice thickness retrievals from satellite sensors.

The capability of sea-ice thickness retrieval using satellite radar and laser altimetry data has been demonstrated for Arctic and Antarctic sea ice (Ricker et al., 2014; Laxon et al., 2013; Kurtz et al., 2014; Zwally et al., 2008; Yi et al., 2011). The altimetry sea-ice thickness retrieval algorithm is based on estimations of freeboard, the height of the ice (ice freeboard) or snow surface (total or snow freeboard) above the local sea level. One fundamental require- 
ment for freeboard retrieval is the interpolation of sea-surface height (SSH) from altimeter range data between leads in the ice cover. The SSH along the satellite ground track forms the reference surface, where the residual of surface elevations over ice gives the freeboard. Sea-ice thickness is then calculated from freeboard using hydrostatic equilibrium equations, requiring estimates of the snow depth and densities of sea ice, snow and water. There are two categories of altimeters currently used for space-borne freeboard measurements. The Geoscience Laser Altimeter System (GLAS) on board the Ice, Cloud and land Elevation Satellite (ICESat, 20032009) measured the distance to the snow/ice surface, hence used snow freeboard as reference interface. Radar altimeters like the Radar Altimeter 2 (RA2) on board Envisat (20022012) or the Synthetic-Aperture Interferometric Radar Altimeter (SIRAL) on board CryoSat-2 (CS-2, since 2010) are based on $K_{u}$-band frequencies. Compared to laser altimetry, radar altimeters have the advantage negligible influence by cloud cover. Contrarily, the surface footprints of radar altimeters are considerably larger than for laser altimeters. An additional complication, especially for sea ice in the Southern Hemisphere, is the location of the main backscattering interface. At $K_{u}$-band frequencies it is originally assumed that the main part of the echo return power originates from the snow/ice interface for dry and cold conditions. In this case radar altimeter range measurements generally relate to ice freeboard. However, the generality of this assumption has been recently questioned by several publications (Willatt et al., 2010, 2011; Ricker et al., 2014; Kurtz et al., 2014; Price et al., 2015; Kwok, 2014).

Over sea ice in the Southern Ocean, Zwally et al. (2008) and Yi et al. (2011) provided a first estimate of snow freeboard and sea-ice thickness distribution and its seasonal evolution in the Weddell Sea using the laser altimeter data from ICESat. They found the highest snow freeboard and the thickest ice in the western Weddell Sea and a clear seasonal cycle of the snow freeboard with the highest values in summer (since all the thin ice is melted away) and lower values in the beginning of winter (due to new ice formation). A comparison between field data and ICESat ground tracks in the Bellingshausen Sea showed a good agreement between both methods (Xie et al., 2011). Recently, Kern and Spreen (2015) estimated the potential uncertainty of sea-ice thicknesses derived from ICESat and AMSR-E snow depths, which ranges between 20 and $80 \%$. They found that the choice of SSH estimation has the highest sensitivity, but reasonable alternatives for lead detections do not result in significant differences. At the same time that the first ICESat snow freeboard maps were developed by Zwally et al. (2008), Giles et al. (2008) also computed freeboard out of radar altimeter data from the European Remote Sensing satellite 2 (ERS-2). In their study they could show that the winter mean freeboard from ERS-2 shows a reasonable distribution and good qualitative agreement with ship-based observations. Later, Price et al. (2015) found a good agreement with field data using
CS-2 radar signals to derive sea-ice freeboard over the fast ice of McMurdo Sound.

Since previous studies show a proof of concept of hemisphere-wide sea-ice thickness retrieval using satellitebased altimeter time series, the next step would be to merge data sets from different satellite missions to a consistent longterm record of Antarctic sea-ice thickness. With the radar altimeters on the ERS-1, ERS-2, Envisat and CryoSat-2 missions of the European Space Agency, a continuous data set spanning 2 decades is available. One particular challenge for a merged time series, however, is the different radar configuration between the pulse-limited altimeters of ERS-1, ERS2 and Envisat and CS-2, which employs along-track beamsharpening for a smaller footprint size. As a result, the characteristics of the radar echo waveform for each single measurement are of inherently different shape for the two radar altimeter types. Range retrieval from the radar waveform is often based on an empirical evaluation of the leading edge, since the full waveform of a sea-ice target is usually of high complexity. Since existing studies on freeboard or thickness are usually based on a single mission, the empirical range retrieval algorithms are not necessarily consistent for different sensor types. Hence, in order to create an inter-sensor time series, we need to test different algorithms on their consistency for different sensors.

Within the ESA Climate Change Initiative (CCI) project Sea Ice - Antarctic Sea-Ice Thickness Option, Envisat and CS-2 freeboard values over the entire Antarctic sea-ice cover have been computed for each data set. A freeboard time series created by those sensors has the potential to cover more than 10 years, from 2002 until today. More importantly, both data sets have a full year of overlap in 2011. This overlap is used to assess a potential inter-mission bias and sensor associated uncertainties based on independently produced monthly mean and modal freeboard values from Envisat and CS-2. Differences are discussed with respect to regional and temporal variability and potential causes are identified. We also relate the differences to the occurrence of the diverse ice classes, i.e., first-year ice (FYI), multiyear ice and coastal ice, for all the ice that occurs close to the coasts (deformed drifting ice, first and multiyear ice as well as landfast ice). This effort is the first towards a development of consistent retrieval algorithms for both pulse-limited and beam-sharpened radar altimeters, with the objective to extend the sea-ice thickness time series in the Southern Ocean back to 1991 with ERS-1 and ERS-2.

\section{Data and methods}

Antarctic-wide freeboard from Envisat and CS-2 data was derived by two different sensor-related processors for the overlap period in 2011. In order to distinguish between open water and sea ice, sea-ice concentration (SIC) is used in both processors. Freeboard was only derived for regions with an 
Table 1. Comparison between characteristics of Envisat and CS-2 and the processors used for freeboard calculations. SSA is sea-surface anomaly derived from detected leads; SIC is sea-ice concentration.

\begin{tabular}{llccccc}
\hline Footprint & $\begin{array}{c}\text { Point } \\
\text { spacing }\end{array}$ & $\begin{array}{c}\text { SIC } \\
\text { product }\end{array}$ & $\begin{array}{c}\text { Automatic } \\
\text { lead } \\
\text { detection }\end{array}$ & $\begin{array}{c}\text { Sea-surface } \\
\text { height }\end{array}$ & Geoid \\
\hline CS-2 & $0.3 \times 1.6 \mathrm{~km}$ & $0.30 \mathrm{~km}$ & OSI SAF & Included & DTU15+ SSA & WGS84 \\
Envisat & $2-10 \mathrm{~km}$ & $0.36 \mathrm{~km}$ & OSI SAF & Included & DTU15+SSA & EGM96 \\
\hline
\end{tabular}

SIC above $55 \%$. Monthly mean freeboard was computed from January to December and was gridded onto a $100 \mathrm{~km}$ EASE-Grid 2.0 (Brodzik et al., 2012). The individual processors are described in Sects. 2.1 and 2.2, and Table 1 gives an overview of the most important processing parameters.

\subsection{CryoSat-2 freeboard retrieval}

The CS-2 freeboard processor has formerly been used for Arctic sea ice and has been adapted for the use of Antarctic sea ice in this study. We use the geolocated level 1b Synthetic Aperture Radar (SAR) and interferometric SAR (SARIn) waveform products over the Southern Ocean $\left(K_{u}\right.$ band, $13.575 \mathrm{GHz}$ ) provided by the ESA (https://earth.esa.int/web/ guest/-/how-to-access-cryosat-data-6842). The surface elevations are processed along individual CS-2 orbits using the Threshold First-Maximum Retracker Algorithm (TFMRA) described by Helm et al. (2014) and Ricker et al. (2014) in detail.

Specifically, the main scattering horizon is tracked at the waveforms' leading edge of the first local maximum by using a power threshold (see Fig. 1). For the processing we define this as threshold of $40 \%$ of first maximum power to retrieve surface elevations. Geophysical range corrections (e.g., ionospheric, tropospheric and tide corrections) are applied using the values supplied in the level $1 \mathrm{~b}$ data files of the ESA. As the exact position of the scattering horizon is unknown we do not apply a correction for the wave propagation speed in the snow layer. Instead we use for our calculation and comparison the freeboard from the uncorrected radar range, termed radar freeboard $\left(F_{\mathrm{R}}\right)$ in contrast to the physical interfaces of either ice or snow freeboard:

$F_{\mathrm{R}}=L-(\mathrm{MSSH}+\mathrm{SSA})$.

$L$ is the retrieved surface elevation, MSSH corresponds to the mean sea-surface height product DTU15 (ftp://space.dtu. $\mathrm{dk} / \mathrm{pub} / \mathrm{DTU} 15)$, which is subtracted from the surface elevations first, in order to remove the main geoid and sea-surface height undulations. The SSA is the sea-surface anomaly derived from linear interpolation between elevations of detected leads along the orbit track and represents the residuum from the MSSH. The sum of MSSH and SSA thus yields the actual SSH for each orbit. The discrimination between open water (leads) and sea ice is based on the waveform and SAR stack parameters such as the right and left pulse peakiness (PP),
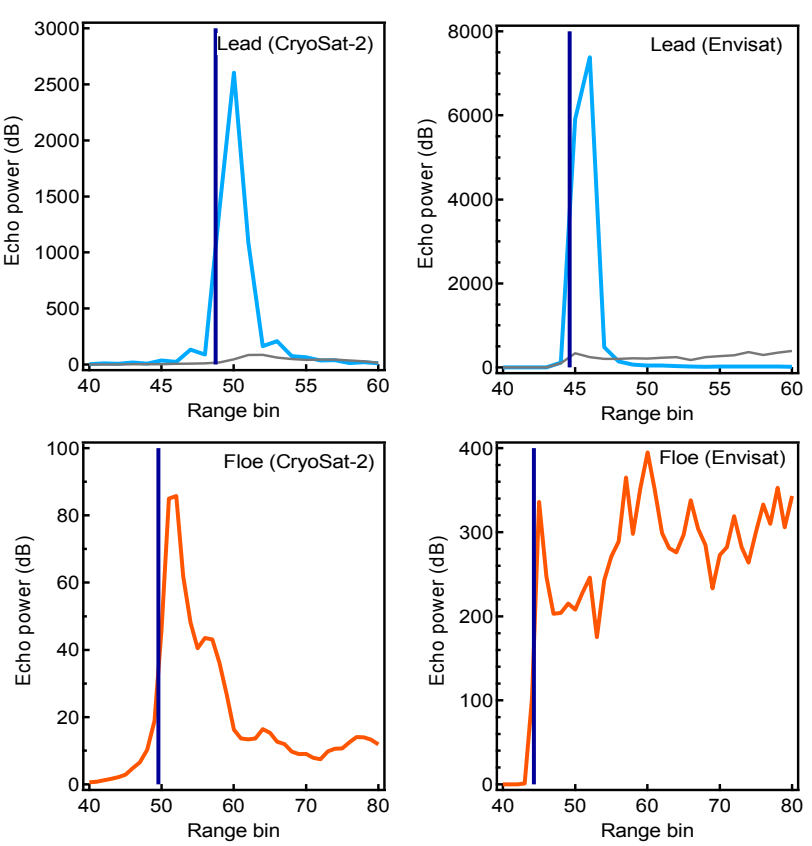

Figure 1. Waveform example for a lead (top panels) and a floe (bottom panels) for CS-2 (left panels) and Envisat (right panels). The blue line shows the retracking point of each waveform. Notice the different scales on the $y$ axis: lead detections have a much higher echo power and a steeper leading edge than waveforms originating from ice only detections. To make the different echo powers better visible, the floe waveforms are shown in the upper figures (leads) in grey. Waveforms from CS-2 and Envisat do not originate from the same position but rather show an arbitrary example.

beam kurtosis, stack standard deviation as well as an ice concentration threshold. A full description is given in Ricker et al. (2014). Leads are cracks in the ice cover and usually have a distinct specular radar echo, while open-ocean and sea-ice surfaces have wider waveforms, resulting from diffuse reflection due to the higher surface roughness (see Fig. 1 for comparison). Data points, which cannot be positively identified as echoes from ice, leads or open ocean, are discarded due to the possibility of a range bias from off-nadir leads (snagging) (Armitage and Davidson, 2014).

Open ocean is identified by using SIC data obtained by the Ocean and Sea Ice Satellite Application Facility (OSI SAF) High Latitude Processing Center (Eastwood, 2012) and pro- 
vided on daily grids with a resolution of $10 \mathrm{~km}$. SIC are interpolated onto the respective CS-2 track in order to define the ice-free areas within the CS-2 freeboard processor along those tracks.

Radar freeboard below $-0.24 \mathrm{~m}$ and above $2.24 \mathrm{~m}$ is discarded from the data sets. Indeed, negative sea-ice freeboard is possible in Antarctica, but the CS-2 signal is certainly reflected at the slush-dry snow interface. We therefore assume a valid range for freeboard footprint averages from 0 to $2 \mathrm{~m}$ but account for speckle range noise $(0.24 \mathrm{~m})$ of the CS-2 orbit data, thus also allowing negative freeboard values. Finally, freeboard values of all CS-2 tracks within a month are compiled and projected onto a $100 \mathrm{~km}$ EASE 2.0 grid for further analysis.

\subsection{Envisat freeboard retrieval}

The input data set for the Envisat freeboard processing is the Envisat Sensor Data Record - SGDR (Sensor Geophysical Data Record) product available from the ESA (https://earth.esa.int/web/guest/data-access/ browse-data-products/-/asset_publisher/y8Qb/content/

Envisat-sensor-data-record-1471). For the processing we used the ESA CCI RA2 prototype processor adapted for the Southern Hemisphere. The processing algorithm is described in detail in the Sea Ice CCI Algorithm Theoretical Basis Document (Ridout and Ivanova, 2012) and the prototype system in the Processing System Description (Kern, 2012).

The Envisat processing is similar to the CS-2 processing described in the Sect. 2.1. Different is the waveform-based surface type classification, where individual radar echoes are segmented in the classes lead, sea ice and unclassified. While CS-2 waveforms are classified using a multi-parameter approach (Ricker et al., 2014), Envisat waveform parameters for classification are limited to the PP defined as (Peacock and Laxon, 2004)

$\mathrm{PP}=\frac{\max (\mathrm{WF})}{\sum_{i=1}^{N_{\mathrm{WF}}} \mathrm{WF}_{i}} \cdot N_{\mathrm{WF}}$.

PP thresholds are used together with SIC information from the OSI SAF daily product to differentiate diffuse waveforms of ice floes or open water and specular returns from leads. Waveforms that do not match either criteria, e.g., due to surface type mixing in the footprint, fall into the unclassified category. Only positively classified waveforms are then retracked to obtain the surface elevation. The surface elevation is referenced to the DTU15 MSS and the residual of the actual SSH interpolated between lead location is subtracted to obtain radar freeboard. As for CS-2, no correction is applied for wave propagation speed in snow so that the derived freeboard refers to the radar freeboard as well.

For Envisat we use different retrackers for leads and floes. For leads we apply the retracker described in Giles et al. (2007). The shape of a specular echo is described by two functions: the first part of the echo is represented by a Gaussian and the second part by an exponentially decaying function. These two functions are linked by a third-degree polynomial function. The functions are fitted to the measured waveform using the Levenberg-Marquardt nonlinear least-squares method and one of the variables is the retracking point. For the ice floes we use a standard OCOG (offset center of gravity) retracker with a $50 \%$ threshold.

In the Envisat processing we discard freeboards smaller than $-1 \mathrm{~m}$ or larger than $2 \mathrm{~m}$. The lower limit for reasonable freeboards is smaller for Envisat than for CS-2 because the noise in Envisat measured elevations is greater. Even though large negative freeboards should not be present, the negative tail of the distribution of Envisat measured freeboards extends below $-0.3 \mathrm{~m}$; thus we have to use a wider window for reasonable freeboards.

\section{Results}

The most basic comparison between CS-2 and Envisat freeboard retrieval is to investigate the spatial and temporal distribution of the respective regional and statistical freeboard distributions. Both data sets show the highest freeboard along the east coast of the Antarctic Peninsula, along the coast of the Bellingshausen/Amundsen Sea and in parts of the Ross Sea, with values of up to $1 \mathrm{~m}$ in the CS-2 data set (Fig. 2). These are the regions which remain ice covered during summer and are known to hold the highest freeboard and the thickest sea ice of the Southern Ocean (e.g., Worby et al., 2008; Giles et al., 2008; Yi et al., 2011). However, Envisat freeboard is generally lower in those regions compared to CS-2 freeboard.

This is also visible in the difference map in Fig. 2, where Envisat freeboard was subtracted from the CS-2 freeboard. Accordingly, red areas indicate that CS-2 has higher freeboard than Envisat, and blue values indicate that Envisat freeboard is higher. During winter months, the Envisat processor yields higher freeboard than CS-2 in large parts of the seasonal first-year sea-ice zone, though in coastal regions and regions with perennial multiyear sea-ice CS-2 reveals higher freeboard. In summer, CS-2 freeboard becomes higher than Envisat freeboard, when all the remaining ice becomes second-year ice. In most regions, the bias lies within $\pm 0.10 \mathrm{~m}$, in particular between May and December. However, it can increase up to $\pm 0.60 \mathrm{~m}$ close to the coasts and in regions with predominantly multiyear ice.

The characteristics of the freeboard distribution, in particular the shape, have been analyzed and compared using histograms covering all grid cells of each product (Fig. 3). The distribution of the freeboard is very broad in summer and fall (January-April). From the end of fall until early summer (May-December), the distribution shows a steep increase towards a distinct mode at low values and a long but flat tail towards the thicker end. The histograms show a similar shape 
Table 2. Modal and mean freeboard, difference between CS-2 and Envisat and root-mean-square error (RMSE) for Antarctic-wide averages.

\begin{tabular}{lccccccccr}
\hline & \multicolumn{2}{c}{ Mean $(\mathrm{m})$} & & \multicolumn{2}{c}{ Mode $(\mathrm{m})$} & & $(\mathrm{m})$ & $(\mathrm{m})$ & \\
\cline { 2 - 3 } & CryoSat-2 & Envisat & & CryoSat-2 & Envisat & Difference & RMSE & No. \\
\hline January & 0.22 & 0.13 & & 0.15 & 0.20 & 0.09 & 0.25 & 165 \\
February & 0.24 & 0.16 & & 0.10 & 0.20 & 0.08 & 0.18 & 141 \\
March & 0.28 & 0.21 & & 0.10 & 0.25 & 0.07 & 0.22 & 175 \\
April & 0.21 & 0.18 & & 0.05 & 0.20 & 0.03 & 0.17 & 357 \\
May & 0.18 & 0.17 & & 0.10 & 0.20 & 0.01 & 0.13 & 723 \\
June & 0.18 & 0.17 & & 0.10 & 0.20 & 0.02 & 0.14 & 976 \\
July & 0.19 & 0.17 & & 0.15 & 0.20 & 0.01 & 0.12 & 1181 \\
August & 0.20 & 0.18 & & 0.15 & 0.20 & 0.01 & 0.13 & 1318 \\
September & 0.20 & 0.19 & & 0.15 & 0.20 & 0.01 & 0.13 & 1353 \\
October & 0.20 & 0.17 & & 0.15 & 0.20 & 0.03 & 0.14 & 1290 \\
November & 0.18 & 0.13 & & 0.10 & 0.20 & 0.05 & 0.16 & 1067 \\
December & 0.18 & 0.10 & & 0.10 & 0.15 & 0.08 & 0.19 & 672 \\
\hline
\end{tabular}

CryoSat-2
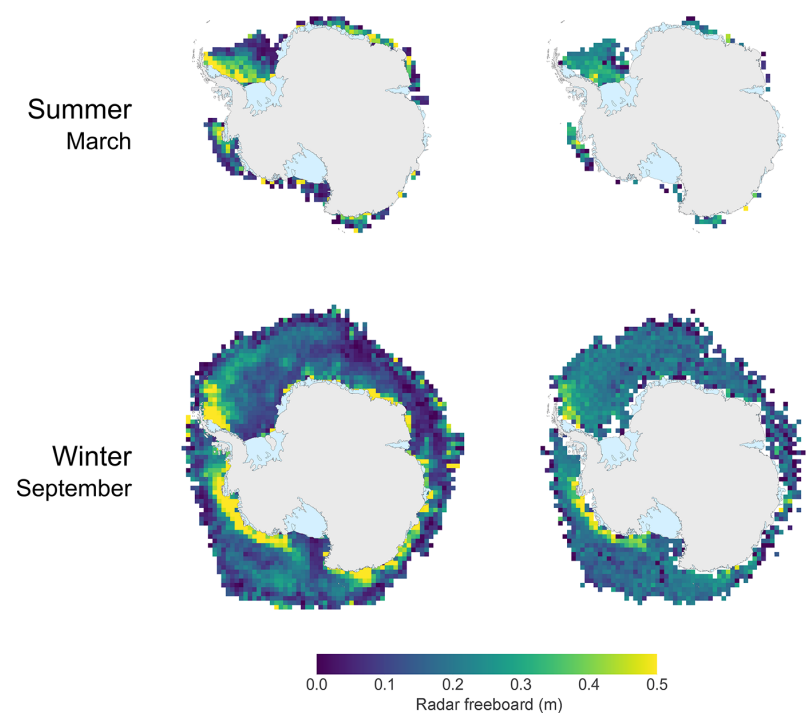

CryoSat-2 - Envisat
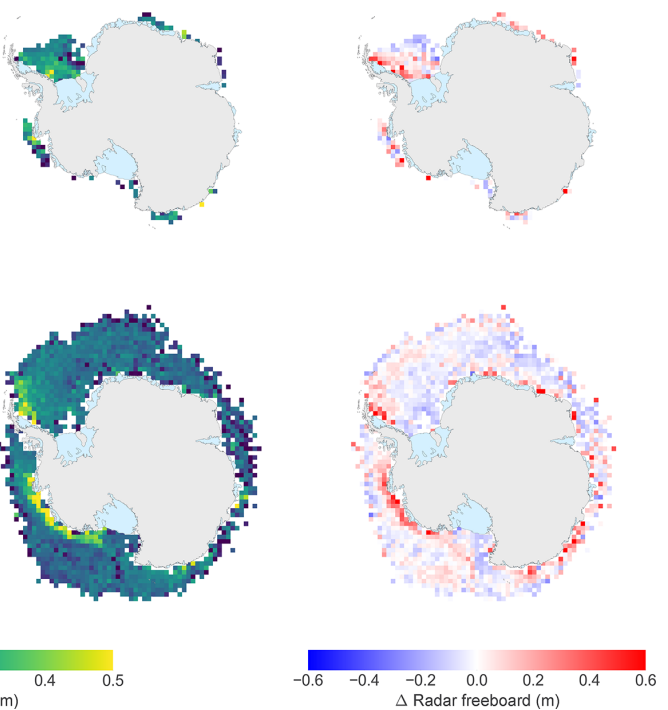

Figure 2. Freeboard maps derived from CS-2 (left panels) and Envisat (center panels), and the difference between both products (right panels) shown for sea-ice minimum in summer (top panels) and maximum in winter (bottom panels). Light blue areas represent the Antarctic ice shelves.

for most months for both data sets, with Envisat freeboard (blue) slightly shifted to higher values compared to CS-2 data (black). Only during fall (March-April), the distributions differ strongly. At the thick end of the distribution, i.e., values above $0.35 \mathrm{~m}$, Envisat freeboard is less strongly represented. However, negative freeboard occurs more often in Envisat data than in CS-2, which is to be expected from the larger noise of along-track Envisat freeboards.

In order to assess a potential inter-mission bias, we calculated Antarctic-wide averages of the monthly mean and modal freeboard over the entire sea-ice zone (Table 2). For this comparison, only data points occurring in both data sets have been taken into account. CS-2 modal freeboard is lower than mean freeboard in all months, like it was also found for sea-ice thickness data from ICESat by Xie et al. (2013); Envisat mean and modal freeboard is generally close to each other with modal values being higher than mean values. Mean freeboard shows a seasonal cycle which is comparable for both data products. In summer, mean freeboard is the highest. With the beginning of the freezing season, it shows a slight decrease; over winter it increases a bit and towards the summer it shows a slight decrease again. The modal freeboard of Envisat is the lowest in the beginning and the highest at the end of summer. For CS-2, modal freeboard decreases 
Table 3. Modal and mean freeboard, the differences between CS-2 and Envisat as well as root-mean-square error for averages in the individual sectors for summer and winter.

\begin{tabular}{|c|c|c|c|c|c|c|c|}
\hline & \multicolumn{2}{|c|}{ Mean (m) } & \multicolumn{2}{|c|}{ Mode (m) } & \multirow{2}{*}{$\begin{array}{r}(\mathrm{m}) \\
\text { Difference }\end{array}$} & \multirow{2}{*}{$\begin{array}{c}(\mathrm{m}) \\
\text { RMSE }\end{array}$} & \multirow[b]{2}{*}{ No. } \\
\hline & CryoSat-2 & Envisat & CryoSat-2 & Envisat & & & \\
\hline \multirow{2}{*}{ Weddell Sea } & 0.28 & 0.23 & 0.25 & 0.25 & 0.04 & 0.17 & 107 \\
\hline & 0.19 & 0.20 & 0.15 & 0.20 & -0.01 & 0.10 & 535 \\
\hline \multirow{2}{*}{ Indian Ocean } & 0.32 & 0.17 & 0.05 & 0.20 & 0.15 & 0.23 & 16 \\
\hline & 0.14 & 0.14 & 0.10 & 0.20 & 0.00 & 0.15 & 199 \\
\hline \multirow{2}{*}{ Western Pacific Ocean } & 0.37 & 0.24 & 0.30 & 0.25 & 0.13 & 0.32 & 12 \\
\hline & 0.26 & 0.18 & 0.10 & 0.20 & 0.08 & 0.21 & 114 \\
\hline \multirow{2}{*}{ Ross Sea } & 0.19 & 0.11 & 0.05 & 0.20 & 0.08 & 0.34 & 11 \\
\hline & 0.19 & 0.19 & 0.20 & 0.20 & 0.01 & 0.11 & 346 \\
\hline \multirow{2}{*}{ Amundsen/Bellingshausen Sea } & 0.30 & 0.18 & 0.10 & 0.25 & 0.12 & 0.27 & 29 \\
\hline & 0.28 & 0.22 & 0.15 & 0.20 & 0.06 & 0.16 & 159 \\
\hline
\end{tabular}

over summer with a minimum in April and increases over the winter with maximum values between July and October.

A similar change from summer to winter sea-ice freeboard, as has been investigated for the mean freeboard, was found by Yi et al. (2011) analyzed from ICESat data. Also Worby et al. (2008) found a similar seasonal cycle for sea-ice thicknesses obtained by ship-based observations (ASPeCt), with the highest mean thicknesses during summer and a lot of thin sea ice influencing the distribution during fall. The high summer values may be caused by the quick disappearance of large areas with FYI in the seasonal ice zone so that the remaining multiyear ice dominates the freeboard and thickness distribution. In the beginning of the freezing season, large areas are then covered by newly formed FYI, which certainly reduces the mean freeboard compared to summer values. The slight increase of mean freeboard over the growth season is in accordance with growing ice over winter. However, it may also be that a change in the penetration depth of the signal causes these high freeboard values. During summer, the location of the reflection horizon of the radar wave may be influenced by wet and/or metamorphous snow (e.g., Kwok, 2014; Willatt et al., 2010). This may lead to an apparent increase of the freeboard compared to winter data, when the radar backscatter or absorption inside the snow layer is less pronounced.

There is a positive bias in the mean freeboard all year round (Table 2), i.e., CS-2 freeboard is on average higher than Envisat freeboard. The highest differences occur during summer, with a maximum of $0.09 \mathrm{~m}$ and a root-meansquare error (RMSE) of $0.25 \mathrm{~m}$ in January. During the sea-ice growth season, between May and October, the lowest differences of about $0.01-0.03 \mathrm{~m}$ with RMSE between 0.12 and $0.14 \mathrm{~m}$ are found. The bias for modal freeboard is instead negative all over the year and does not follow a seasonal cycle. The maximum difference for modal freeboard can be found at the end of spring, in March and April. Over the rest of the year, it remains rather constant with values lower than or equal to $0.1 \mathrm{~m}$, considering $5 \mathrm{~cm}$ intervals.

For the individual sectors of the Southern Ocean (following the sector classification in Parkinson and Cavalieri, 2012), the occurrence of multiyear and seasonal ice has a varying impact on mean and modal freeboard (see Table 3 for summer and winter values, exemplarily). In the Ross Sea, the bias for the mean radar freeboard is negative from April to August. In the Weddell Sea it is negative in August only. The Ross Sea and Weddell Sea are the regions with the largest SIE; hence, a lot of seasonal ice and free-drifting sea ice far away from the coast is apparent in those sectors. Therefore, the total bias becomes partly negative over winter, when the area, and therefore the impact, of the multiyear ice becomes less pronounced compared to the total SIE. Over summer, the percentage of those ice classes increases again and, therefore, both regions show a positive bias; i.e., CS-2 shows on average higher freeboard values than Envisat. In the Indian Ocean sector, the Western Pacific Ocean and the Bellingshausen/Amundsen Sea, either the multiyear sea ice or the impact of coastal ice dominates and leads to a yearround positive bias in mean freeboard. The combination of both effects, the higher CS-2 freeboard in the multiyear seaice zone and near the coast and the lower CS-2 freeboard in the seasonal pack-ice zone, leads to a high positive bias in summer and a nearly balanced (zero) one during winter for data averaged over the entire Antarctic sea-ice zone. However, the differences in the modal freeboard are for all regions for most months negative, which indicates that most of the ice-covered grid cells have higher values for Envisat data. A positive difference can be found in the Indian Ocean sector (January), the Western Pacific Ocean sector (JanuaryMarch, December), the Ross Sea (only February) and the Amundsen/Bellingshausen Sea (February) only in the sum- 

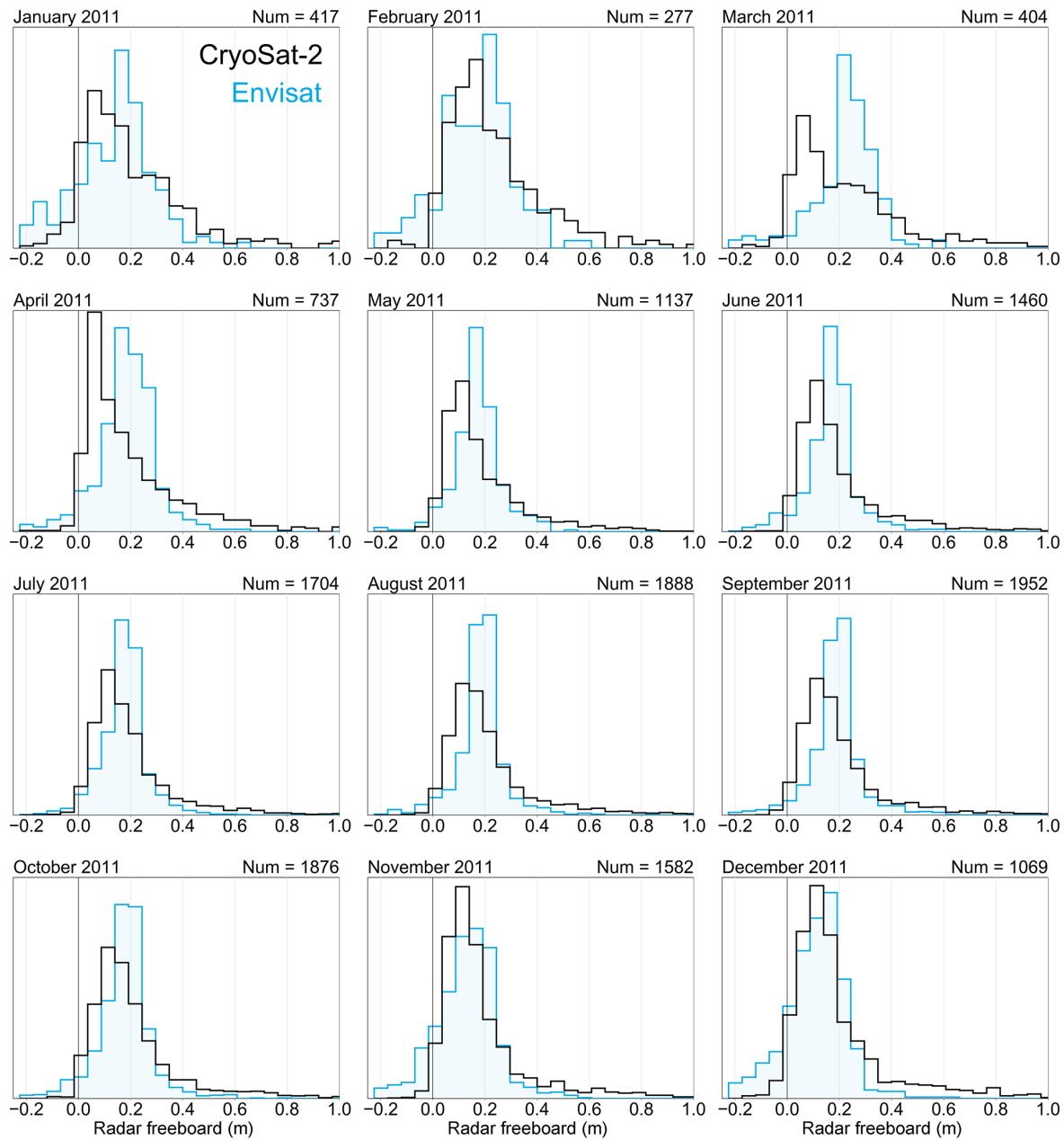

Figure 3. Histograms of freeboard distribution for CS-2 (black) and Envisat (blue) data. Only data occurring in both data sets have been considered. $n$ is the number of compared grid cells.

mer months, when most of the ice is the multiyear and coastal sea ice. Most of the differences for (sectional) modal freeboard are lower than or equal to $\pm 0.1 \mathrm{~m}(88 \%)$, in a lot of months it is even lower than or equal to $\pm 0.05 \mathrm{~m}$ (about $58 \%$, considering $5 \mathrm{~cm}$ intervals).

\section{Discussion}

The present study investigates the consistency between Envisat and CS-2 radar freeboard developed independently from each other within ESA CCI project Sea Ice. We found a reasonable agreement for the regional distribution of freeboard, with thicker radar freeboard in the regions with multiyear ice. However, Envisat freeboard tends to be higher than CS-2 in the first-year sea-ice zone while CS-2 data are higher compared to Envisat along the coast and in the multiyear sea-ice zone. A simple change in the retracker threshold would not solve this ice-type-dependent mismatch because such a modification changes all freeboard values only in one direction. Furthermore, although both products reveal negative freeboard (Fig. 3), Envisat shows higher fractions. This might be caused by the coarser spatial resolution, leading to an erroneous sea-surface height interpolation, as well as by the difference in noise level and accordingly the cut-off windows for both products. In any case, we do not expect that this negative freeboard is related to flooded sea ice, since the radar signal would not penetrate through the flooded layer.

In order to investigate potential causes for the differences in both data sets, we compared the lead fractions within the grid cell of CS-2 and Envisat freeboard (Fig. 4). The goal was to assess whether a difference in the lead fraction between both data sets may lead to different SSAs and thus to differences in the respective radar freeboards. The lead fraction is generally much higher for Envisat than for CS-2, but they share a similar regional pattern. We can speculate that the reason for the high Envisat lead fractions is due the larger pulse-limited footprint that increases the probability for radar returns from mixed surfaces. The radar altimeter on board 
CryoSat-2
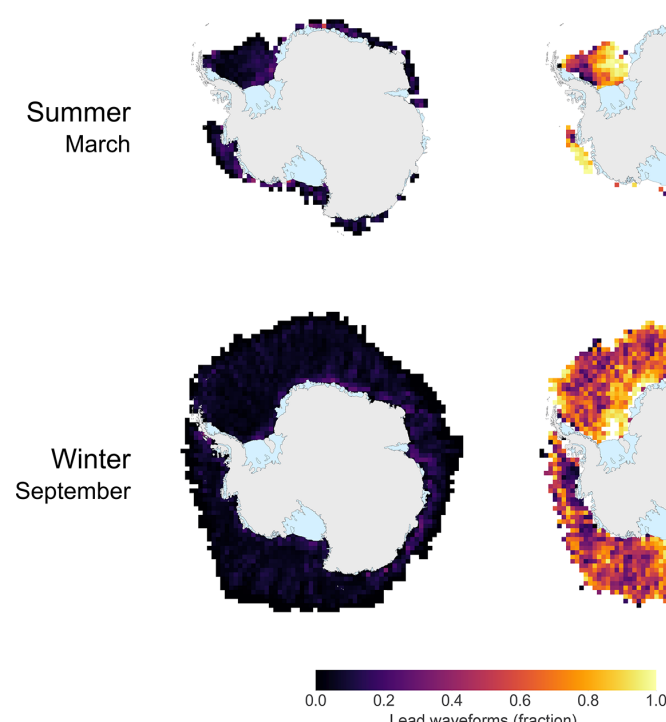

Envisat
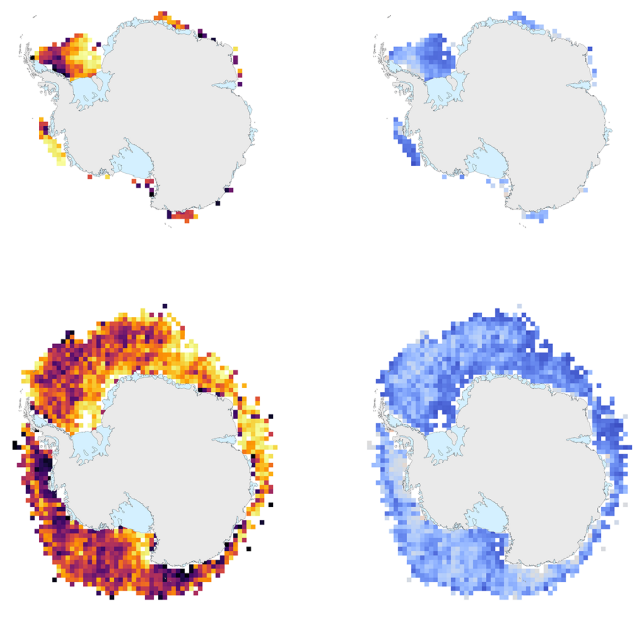

$0.0 .8-0.6-0.4-0.2 \quad 0.0 \quad 0.2 \quad 0.4 \quad 0.6 \quad 0.8 \quad 1.0$ $\Delta$ Lead waveforms (fraction)

Figure 4. Fraction of waveforms that are identified as leads, for Antarctic summer and winter: CS-2 (left panels), Envisat (center panels) and the difference CS-2-Envisat (right panels). Blue values in the right-hand figure indicate that within a grid cell, more waveforms for Envisat are classified as leads than for CS-2.

Envisat has a much coarser resolution and lower data coverage than the one on board CS-2. Due to the delay/Doppler processing, the CS-2 footprint corresponds to the size of a Doppler cell, which is approximately $300 \times 1600 \mathrm{~m}$ (Wingham et al., 2006), while Envisat has a footprint of 2-10 km (Connor et al., 2009). Envisat waveforms from mixed surfaces are often discarded since they do not match the classification scheme. Hence, the fraction of lead waveforms to positively identified waveforms is significantly higher for Envisat than for CryoSat-2, which suffers less from surface type mixing due to a smaller radar footprint. Also, it is reasonable to assume that the impact of Envisat footprint size on surface type classification causes a selection bias of certain ice types (e.g., preferential sampling of large floes) and thus could partly explain the observed differences in radar freeboard.

Less pronounced are the differences in the SSA results of both sensors (Fig. 5). While the SSA shows a consistent low in the central Weddell Sea in both results, a clear offset is visible in the differences of the CS-2 and Envisat SSA estimations. The residual offset is most likely caused by deviating absolute range values due to different geophysical range corrections. This is supported by the lack of regional patterns in the difference of the two SSA estimations. This indicated that the lead detections and sea-surface height estimation between both sensors is in good agreement.

Besides the impact on surface type classification, the lowpass filtering effect of the larger Envisat footprint has the potential to directly impact the gridded freeboard. Thus, the corresponding CS-2 freeboard grid captures more regional variability of the sea-ice cover, while, in contrast, the Envisat freeboard appears smoother. A study dealing with the impact that different footprint sizes has on mean and modal freeboard in the Arctic (Schwegmann et al., 2014) showed that differences of $0.1-0.2 \mathrm{~m}$ for modal and $0.005 \mathrm{~m}$ for mean values can be expected for footprints varying from point measurements, over the ICESat footprint of $70 \mathrm{~m}$ to a footprint of $300 \mathrm{~m}$ (according to the along-track footprint of CS-2). A similar result was found by Xie et al. (2013), who compared sea-ice thicknesses derived from ICESat data on the $70 \mathrm{~m}$ ICESat footprint and upscaled to the AMSR-E scale of $12.5 \times 12.5 \mathrm{~km}$. Hence, partially, the difference between CS-2 and Envisat mean and modal freeboard may simply be caused by the different footprint and resolution of both measurement systems.

Moreover, discrepancies might also be given by the fact that Envisat uses two individual retrackers for floes and leads. It is not well established how well results from different retracking approaches relate to each other in different surface roughness scenarios. For the Arctic, a possible bias in a few marginal ice zones was tested for (assuming that the actual ice freeboard of very thin ice is 0 ), but no bias was found. This could be different in the Antarctic, though it is not likely. The CS-2 processing instead is based on a uniform approach for lead and ice waveforms. This decision is based less on physical considerations but rather evolved from a process where CS-2 radar freeboards were compared to airborne validation data in the Arctic. However, the performance analysis of retracker algorithms requires extensive airborne validation data for 2011 that we do not yet have available. This is also 
CryoSat-2
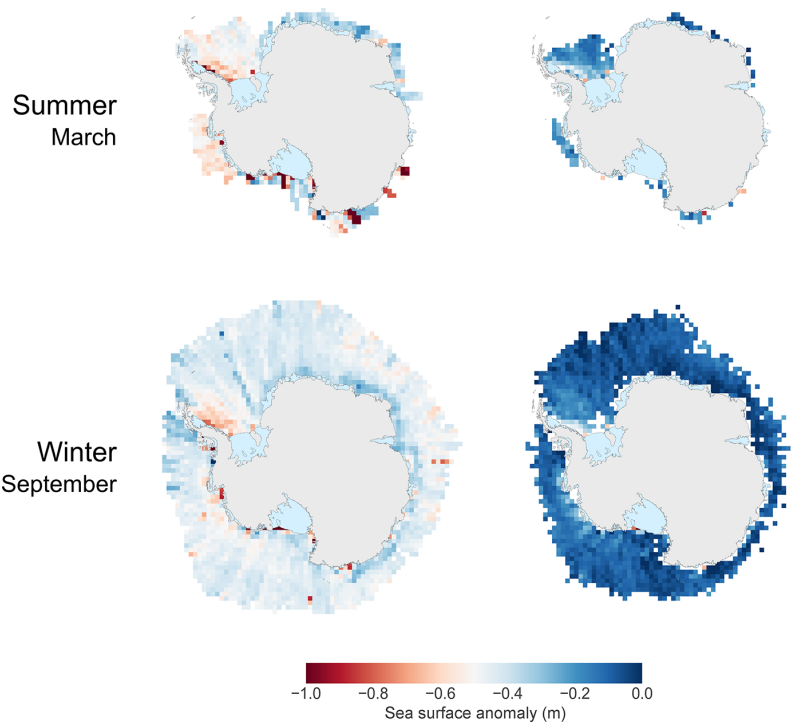

Envisat

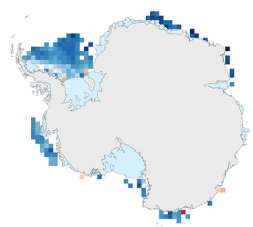

CryoSat-2 - Envisat
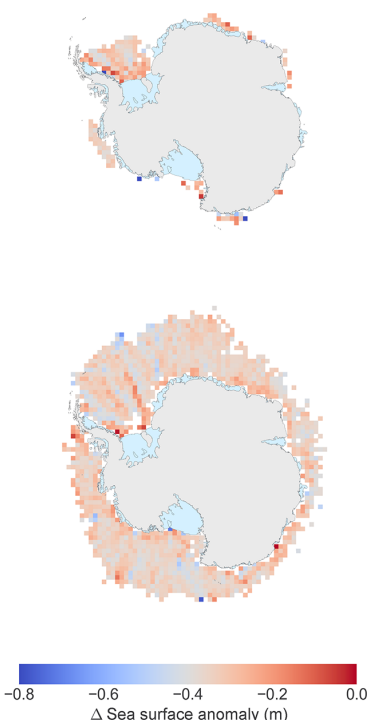

Figure 5. Sea-surface anomaly for summer (top panels) and winter (bottom panels), derived from CryoSat-2 (left panels) and Envisat (center panels), and the difference between both products. The difference plot indicates a bias between the CryoSat-2 and the Envisat sea-surface height.

the reason why we do not provide information on the accuracy of either freeboard products or an answer to the question whether $K_{u}$-band radar altimeter signals originate from the snow/ice or snow/air interface or from somewhere inbetween. A study of Price et al. (2015) indicated that the reflection horizon of CS-2 data over Antarctic sea ice, derived with a retracker threshold of $40 \%$, is certainly close to the snow/air interface. However, Operation IceBridge laser freeboard measurements over Antarctic sea ice as well as laser altimeter data from the R/V Polarstern expedition PS81 in winter 2013 and PS89 in summer 2014/2015 are expected to be available in the near future. These data sets will only enable a validation of CS-2 radar freeboard products in the Southern Hemisphere. We have therefore limited this study to a consistency assessment between the two radar altimeter types, knowing that future improvements due to CS-2 validation efforts have to propagate to the Envisat and ERS1/2 eras.

\section{Conclusions and outlook}

This study rooted in ESA CCI project Sea Ice aimed to investigate whether the radar freeboard estimates from CS-2 and Envisat are consistent so that both time series can be merged without intermission biases. The comparison revealed a reasonable regional agreement between radar freeboards derived from pulse-limited (Envisat) and beam-sharpened (CS2 ) waveforms. Differences are mostly below $0.1 \mathrm{~m}$ for modal freeboard and even less for mean freeboard over winter months (May-October), although the difference in first-year to multiyear regions is much more pronounced in CS-2 than Envisat radar freeboard. The highest differences occur in regions with multiyear sea ice and along the coasts. In general, the dynamic range of CS-2 freeboard is higher than for Envisat and due to the higher spatial resolution, CryoSat-2 is less affected by surface type mixing in the radar footprint. Also, the fraction of waveforms associated to leads is significantly higher for Envisat than CS-2 leading to a potential preferential sampling of larger ice floes and thus to higher freeboard in the first-year ice. Results from this study can be used as to direct consistency improvements between pulselimited and beam-sharpened radar altimetry over sea ice. The observed differences when using results from existing approaches call for an in-depth investigation of Envisat-type waveform characteristics, their impact on surface type classification and a review of retracking approaches. This effort requires additional data sets on the actual physical snow and ice conditions and such an undertaking is out of the scope of this study. For the future, we are confident that this study by highlighting regions with apparent lack of consistency serves as a baseline for further algorithm development with the ultimate goal to extend the time series of sea-ice thickness observations towards decadal time series with ERS-1/2 data.

Acknowledgements. This research was funded by the European Space Agency Climate Change Initiative Sea Ice projects SK-ESA2012-12 and NERSC-ESA-2014-2. The work of Stefan Hendricks and Veit Helm was funded by the German Federal Ministry of 
Economics and Technology (grant 50EE1331). We would like to thank ESA, OSI SAF and DTU for providing all the data needed for freeboard processing and the editor and the reviewers for their valuable comments.

Edited by: J.-L. Tison

\section{References}

Armitage, T. W. K. and Davidson, M. W. J.: Using the Interferometric Capabilities of the ESA CryoSat-2 Mission to Improve the Accuracy of Sea Ice Freeboard Retrievals, IEEE T. Geosci. Remote, 52, 529-536, 2014.

Behrendt, A., Dierking, W., Fahrbach, E., and Witte, H.: Sea ice draft in the Weddell Sea, measured by upward looking sonars, Earth Syst. Sci. Data, 5, 209-226, doi:10.5194/essd-5-209-2013, 2013.

Brodzik, M. J., Billingsley, B., Haran, T., Raup, B., and Savoie, M. H.: EASE-Grid 2.0: Incremental but Significant Improvements for Earth-Gridded Data Sets, ISPRS Int. J. Geo-Inform., 1, 3245, 2012.

Connor, L. N., Laxon, S. W., Ridout, A. L., Krabill, W. B., and McAdoo, D. C.: Comparison of Envisat radar and airborne laser altimeter measurements over Arctic sea ice, Remote Sens. Environ., 113, 563-570, 2009.

Dierking, W.: Laser Profiling of the Ice Surface-Topography during the Winter Weddell Gyre Study 1992, J. Geophys. Res.-Oceans, 100, 4807-4820, 1995.

Eastwood, S.: OSI SAF Sea Ice Product Manual, available at: http: //osisaf.met.no (last access: 10 January 2014), 2012.

Giles, K. A., Laxon, S. W., Wingham, D. J., Wallis, D. W., Krabill, W. B., Leuschen, C. J., McAdoo, D., Manizade, S. S., and Raney, R. K.: Combined airborne laser and radar altimeter measurements over the Fram Strait in May 2002, Remote Sens. Environ., 111, 182-194, 2007.

Giles, K. A., Laxon, S. W., and Worby, A. P.: Antarctic sea ice elevation from s atellite radar altimetry, Geophys. Res. Lett., 35, L03503, doi:10.1029/2007GL031572, 2008.

Haas, C.: Evaluation of ship-based electromagnetic-inductive thickness measurements of summer sea-ice in the Bellingshausen and Amundsen Seas, Antarctica, Cold Reg. Sci. Technol., 27, 1-16, 1998.

Haas, C., Nicolaus, M., Willmes, S., Worby, A., and Flinspach, D.: Sea ice and snow thickness and physical properties of an ice floe in the western Weddell Sea and their changes during spring warming, Deep-Sea Res. Pt. II, 55, 963-974, 2008.

Harms, S., Fahrbach, E., and Strass, V. H.: Sea ice transports in the Weddell Sea, J. Geophys. Res.-Oceans, 106, 9057-9073, 2001.

Helm, V., Humbert, A., and Miller, H.: Elevation and elevation change of Greenland and Antarctica derived from CryoSat2, The Cryosphere, 8, 1539-1559, doi:10.5194/tc-8-1539-2014, 2014.

Kern, S.: Sea Ice Climate Change Initiative Phase 1, Product Specification Document, ESA Document, Doc Ref. SICCI-PSD-0212, ESA, http://esa-cci.nersc.no/?q=webfm_send/181 (last access: July 2016), 2012.

Kern, S. and Spreen, G.: Uncertainties in Antarctic sea-ice thickness retrieval from ICESat, Ann. Glaciol., 56, 107-119, 2015.
Kurtz, N. T., Galin, N., and Studinger, M.: An improved CryoSat-2 sea ice freeboard retrieval algorithm through the use of waveform fitting, The Cryosphere, 8, 1217-1237, doi:10.5194/tc-8-12172014, 2014.

Kwok, R.: Simulated effects of a snow layer on retrieval of CryoSat2 sea ice freeboard, Geophys. Res. Lett., 41, 5014-5020, 2014.

Lange, M. A. and Eicken, H.: The Sea Ice Thickness Distribution in the Northwestern Weddell Sea, J. Geophys. Res.-Oceans, 96, 4821-4837, 1991.

Laxon, S. W., Giles, K. A., Ridout, A. L., Wingham, D. J., Willatt, R., Cullen, R., Kwok, R., Schweiger, A., Zhang, J. L., Haas, C., Hendricks, S., Krishfield, R., Kurtz, N., Farrell, S., and Davidson, M.: CryoSat-2 estimates of Arctic sea ice thickness and volume, Geophys. Res. Lett., 40, 732-737, 2013.

Leuschen, C. J., Swift, R. N., Comiso, J. C., Raney, R. K., Chapman, R. D., Krabill, W. B., and Sonntag, J. G.: Combination of laser and radar altimeter height measurements to estimate snow depth during the 2004 Antarctic AMSR-E Sea Ice field campaign, J. Geophys. Res.-Oceans, 113, C04S90, doi:10.1029/2007JC004285, 2008.

Lindsay, R. and Schweiger, A.: Arctic sea ice thickness loss determined using subsurface, aircraft, and satellite observations, The Cryosphere, 9, 269-283, doi:10.5194/tc-9-269-2015, 2015.

Ozsoy-Cicek, B., Ackley, S., Xie, H. J., Yi, D. H., and Zwally, J.: Sea ice thickness retrieval algorithms based on in situ surface elevation and thickness values for application to altimetry, J. Geophys. Res.-Oceans, 118, 3807-3822, 2013.

Parkinson, C. L. and Cavalieri, D. J.: Antarctic sea ice variability and trends, 1979-2010, The Cryosphere, 6, 871-880, doi:10.5194/tc-6-871-2012, 2012.

Peacock, N. R. and Laxon, S. W.: Sea surface height determination in the Arctic Ocean from ERS altimetry, J. Geophys. Res.Oceans, 109, C07001, doi:10.1029/2001JC001026, 2004.

Perovich, D. K., Elder, B. C., Claffey, K. J., Stammerjohn, S., Smith, R., Ackley, S. F., Krouse, H. R., and Gow, A. J.: Winter sea-ice properties in Marguerite Bay, Antarctica, Deep-Sea Res. Pt. II, 51, 2023-2039, 2004.

Price, D., Beckers, J., Ricker, R., Kurtz, N., Rack, W., Haas, C., Helm, V., Hendricks, S., Leanoard, G., and Langhorne, P. J.: Evaluation of CryoSat-2 derived sea-ice freeboard over fast ice in McMurdo Sound, Antarctica, J. Glaciol., 61, 285-300, 2015.

Ricker, R., Hendricks, S., Helm, V., Skourup, H., and Davidson, M.: Sensitivity of CryoSat-2 Arctic sea-ice freeboard and thickness on radar-waveform interpretation, The Cryosphere, 8, 16071622, doi:10.5194/tc-8-1607-2014, 2014.

Ridout, A. and Ivanova, N.: Sea Ice Climate Change Initiative Phase 1, Algorithm Theoretical Basis Document (ATBDv0), ESA Document, Doc Ref. SICCI-ATBDv007-12, ESA, https://icdc.zmaw.de/fileadmin/user_upload/ESA_ Sea-Ice-ECV/SICCI_ATBDv2_D3.6_Issue_1.0.pdf (last access: July 2016), 2012.

Rothrock, D. A., Yu, Y., and Maykut, G. A.: Thinning of the Arctic sea-ice cover, Geophys. Res. Lett., 26, 3469-3472, 1999.

Rothrock, D. A., Percival, D. B., and Wensnahan, M.: The decline in arctic sea-ice thickness: Separating the spatial, annual, and interannual variability in a quarter century of submarine data, J. Geophys. Res.-Oceans, 113, C05003, doi:10.1029/2007JC004252, 2008. 
Schwegmann, S., Hendricks, S., Haas, C., and Herber, A.: Effects of different footprint areas on the comparability between measurements of sea ice freeboard, IGS International Symposium on Sea Ice in a Changing Environment, 10-14 March 2014, Hobart, Tasmania, Australia, http://epic.awi.de/35386/ (last access: June 2016), 2014.

Wadhams, P., Lange, M. A., and Ackley, S. F.: The Ice Thickness Distribution across the Atlantic Sector of the Antarctic Ocean in Midwinter, J. Geophys. Res.-Oceans, 92, 14535-14552, 1987.

Weissling, B. P., Lewis, M. J., and Ackley, S. F.: Sea-ice thickness and mass at Ice Station Belgica, Bellingshausen Sea, Antarctica, Deep-Sea Res. Pt. II, 58, 1112-1124, 2011.

Willatt, R., Laxon, S., Giles, K., Cullen, R., Haas, C., and Helm, V.: $\mathrm{Ku}$-band radar penetration into snow cover Arctic sea ice using airborne data, Ann. Glaciol., 52, 197-205, 2011.

Willatt, R. C., Giles, K. A., Laxon, S. W., Stone-Drake, L., and Worby, A. P.: Field Investigations of Ku-Band Radar Penetration Into Snow Cover on Antarctic Sea Ice, IEEE T. Geosci. Remote, 48, 365-372, 2010.

Wingham, D. J., Francis, C. R., Baker, S., Bouzinac, C., Brockley, D., Cullen, R., de Chateau-Thierry, P., Laxon, S. W., Mallow, U., Mavrocordatos, C., Phalippou, L., Ratier, G., Rey, L., Rostan, F., Viau, P., and Wallis, D. W.: CryoSat: A mission to determine the fluctuations in Earth's land and marine ice fields, Nat. Hazards Oceanogr. Process. Sat. Data, 37, 841-871, 2006.
Worby, A. P., Geiger, C. A., Paget, M. J., Van Woert, M. L., Ackley, S. F., and DeLiberty, T. L.: Thickness distribution of Antarctic sea ice, J. Geophys. Res.-Oceans, 113, C05S92, doi:10.1029/2007JC004254, 2008.

Xie, H., Ackley, S. F., Yi, D., Zwally, H. J., Wagner, P., Weissling, B., Lewis, M., and Ye, K.: Sea-ice thickness distribution of the Bellingshausen Sea from surface measurements and ICESat altimetry, Deep-Sea Res. Pt. II, 58, 1039-1051, 2011.

Xie, H., Tekeli, A., Ackley, S., Yi, D., and Zwally, J.: Sea ice thickness estimations from ICESat Altimetry over the Bellingshausen and Amundsen Seas, 2003-2009, J. Geophys. Res., 118, 2438 2453, doi:10.1002/jgrc.20179, 2013.

Yi, D. H., Zwally, H. J., and Robbins, J. W.: ICESat observations of seasonal and interannual variations of sea-ice freeboard and estimated thickness in the Weddell Sea, Antarctica (2003-2009), Ann. Glaciol., 52, 43-51, 2011.

Zwally, H. J., Yi, D. H., Kwok, R., and Zhao, Y. H.: ICESat measurements of sea ice freeboard and estimates of sea ice thickness in the Weddell Sea, J. Geophys. Res.-Oceans, 113, C02S15, doi:10.1029/2007JC004284, 2008. 